\title{
Optimalisai Pembelajaran Abad 21 Pada SMP dan SMA
}

\author{
Yulianda Putri Rahmawatii ${ }^{*}$, Mohammad Salehudin ${ }^{2}$ \\ 1,2 Prodi PAI FTIK Universitas Islam Negeri Sultan Aji Mauhammad Idris Samarinda, Indonesia \\ *email: yuliandaputrii12@gmail.com (Corresponding Author)
}

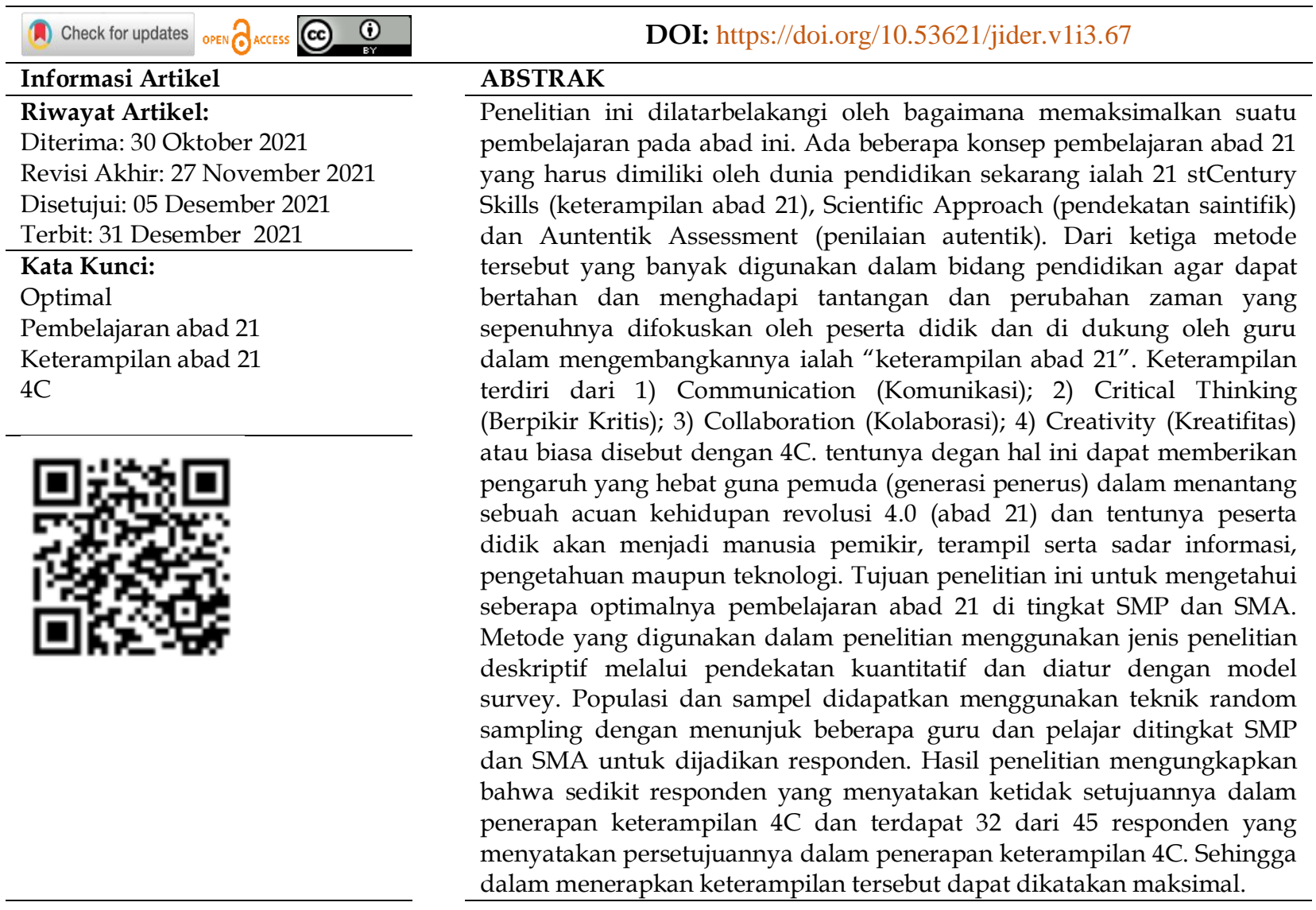

\section{PENDAHULUAN}

Pada tahun 2000 hingga sekarang ini kita berada pada abad yang biasa disebut dengan abad 21, atau bisa juga disebut dengan abad revolusi 4.0, dimana pada abad ini kemajuan IPTEK sangat pesat dan luas. Dengan kemajuan IPTEK yang sangat pesat dan luas, mengharuskan peserta didik agar dapat mengikuti serta beradaptasi dengan kemajuan tersebut. Kemendikbud RI sudah mengorientasi 3 konsep pendidikan pada abad 21 dalam bentuk meningkatkan kurikulum yang baru, baik bagi Sekolah Dasar, Sekolah Menengah Pertama, Sekolah Menengah Atas maupun Sekolah Menengah Kejuruan. Ketiga konsep yang dimaksud tersebut yaitu, 21 stCentury Skills (keterampilan abad 21), Scientific Approach (pendekatan saintifik) dan Auntentik Assessment (penilaian autentik) (Junedi et al., 2020).

Dari salah satu konsep tersebut, dalam suatu pendidikan harus mampu menanamkan "keterampilan abad 21" kepada peserta didik, agar peserta didik khususnya sekolah menengah pertama dan sekolah menengah kebawah dapat bertahan dan menghadapi tantangan dan perubahan zaman (Astutik \& Hariyati, 2021). Dalam penataran di abad revolusi 4.0 ini, anak didik harus mempunyai kecakapan dalam Learning and Innovation yang terdiri dari 1) Communication (Komunikasi); 2) Critical 
Thinking (Berpikir Kritis); 3) Collaboration (Kolaborasi); 4) Creativity (Kreatifitas) atau biasa disebut dengan 4C (Wirawan \& Sukarni, 2013). Apabila sungguh-sungguh dilaksanakan di pendidikan, implementasi 4C dalam penataran kurikulum 2013 akan memberikan pengaruh yang hebat guna pemuda (generasi penerus) dalam menantang sebuah acuan kehidupan revolusi 4.0 (abad 21) dan tentunya peserta didik akan menjadi manusia pemikir, terampil serta sadar informasi, pengetahuan maupun teknologi (Aliftika \& Purwanto Utari, 2019, Astutik \& Hariyati, 2021).

Permasalahan yang terjadi pada abad 21 mengenai perkembangan IPTEK maupun system pembelajaran di sekolah salah satunya ialah saat ini paling banyak beredar informasi di internet yang tidak valid (Hoax) yang menyebabkan peserta didik mudah percaya terhadap informasi yang beredar. Adapun permasalah lainnya di kurikulum 2013 pada pendidikan menengah kebawah. Kurikulum 2013 tersebut sebenarnya telah mendukung keahlian pada abad 21 dari berbagai standar yang ada yaitu, standar proses, isi maupun penilaian. Pendeketan saintifik pada standar proses sebenarnya sudah diterapkan pada pembelajaran menengah pertama maupun menengah atas. Namun kejadian dilapangan banyak pembelajaran yang dilakukan yaitu pembelajaran yang tengah bertaut pada guru atau bisa disebut dengan teacher-centered. Hal ini berakibat peserta didik tidak optimal dalam memahami keahlian revolusi 4.0 (Redhana, 2019)

Bertolak belakang dengan apa yang seharusnya dilakukan peserta didik dalam menghadapi tantangan abad revolusi 4.0. maka dari itu peserta didik tidak hanya menerapkan $4 \mathrm{C}$ dalam pendidikan, tetapi juga dapat memegang teguh literasi-literasi yang ada (teknologi, informasi dan komunikasi). sehingga peserta didik tidak mudah percaya terhadap berita "Hoax" dan pandai dalam menggunakan komunikasi di berbagai teknologi di era sekarang ini. Dan jawaban dari system pembelajaran yang bertaut pada guru (teacher-centered) solusi yang tepat dalam pembaruan pembelajaran ini yaitu beralih kepada system pembelajaran yang bertaut pada peserta didik (Redhana, 2019).

Berdasarkan uraian diatas, pembelajaran abad 21 memiliki tujuan dalam menambah kemampuan peserta didik yang afektif dan kognitif agar dapat mengikuti perkembangan dan bersaing dengan melewati sebuah proses keterampilan abad 21 . Dan tujuan dari penelitian ini adalah untuk mengetahui seberapa optimalnya pembelajaran pada abad 21 di SMP dan SMA.

\section{KAJIAN PUSTAKA}

Istilah pengajaran yakni perubahan dari Pembelajaran. Pembelajaran ialah sebuah upaya yang dilaksanakan oleh guru dalam mengajari serta meneruskan pengkajian kepada peserta didik yang menuntut ilmu. Guru selaku jiwa yang profesional memiliki persiapan dalam menemui perkembangan abad 21 (Ninla Elmawati Falabiba, 2019). Dalam model pelajaran pada abad 21 ini sangatlah penting dalam meningkatkan keahlian berfikir peserta didik agar dapat berasumsi, memiliki keahlian dalam TIK serta mengaitkan suatu ilmu dengan dunia yang nyata. Dalam mencapai suatu keahlian tersebut membutuhkan yang namanya metode pembelajaran yang tepat dalam bidang kecakapan materi dan kapabilitas (Hasanah \& Malik, 2019).

Karakteristik pada saat ini tentunya mewujudkan pengajaran abad 21 serta berakibat pada evaluasi revolusi 4.0. Karakteristik yang sangat mencolok pada abad 21 ialah memiliki jaringan media sosial (online social networking), permainan daring (game online), Multitasking (multitasking), pencarian daring (online in for searching), dan 
Multimedia (multimedia) (Junedi et al., 2020). Menurut Rotherdam \& Willingham yang dikutip oleh Dyna Natalia dalam analisis artikel dapat ditemukan bahwa "keberhasilan anak didik dapat dilihat dari keterampilan dalam abad 21 yang mewajibkan anak didik untuk menuntut ilmu dan memahaminya". Dan menurut Anderson \& Krathwohl pembelajaran abad 21 juga memiliki strategi yang wajib diperhatikan dalam mengukur cara wawasan ialah psikomotor, afektif dan kognitif.

Sedangkan Menurut Educational Testing Service (ETS) yang dikutip oleh Dyna Natalia memaparkan, bahwa abad 21 ialah "suatu upaya analisis pengkajian yang dilaksanakan supaya anak didik memiliki daya untuk menghimpun bahan ataupun memahami, mengatur serta dapat menata suatu informasi, menganalisis dan membuat suatu informasi yang tepat setara dengan sumber daya yang dipergunakan" (Ninla Elmawati Falabiba, 2019). Dengan kata lain pembelajaran abad 21 menekankan agar peserta didik menjadi pusat dalam proses pembelajaran (student centered) yang memiliki keahlian berfikir secara kritis, dapat memecahkan suatu permasalahan, berkomunikasi dengan baik, memiliki inovasi dan berkreatif, metakognisi, literasi informasi serta berkolaborasi. Tidak hanya itu guru juga berperan secara aktif dalam membantu anak didik mengembangkan potensinya dan mendukung anak didiknya dalam melaksanakan cita-cita dengan memberikan persiapan yang berupa ilmu (Digital \& Conference, 2021).

\section{METODE PENELITIAN}

\section{Rancangan Penelitian}

Metode yang digunakan dalam penelitian ini ialah metode deskriptif dengan pendekatan kuantitatif. Metode deskriptif ialah seperti suatu ringkasan kejadian yang berhubungan dengan penjelasanakan akan keberadaan variabel yang berdiri sendiri baik satu variabel atau lebih (Sari \& Hartini, 2020). Dengan jenis penelitian deskriptif kuantitatif ini, teknik pengumpulan data yang akan menjadi sumber data untuk menyempurnakan sebuah penelitian, dan diatur dengan model survey (Salehudin et al., 2020). Hasil dari data kuantitatif diperlukan dalam skema presentase, dan dipertunjukkan dalam skema deskriptif Kuantitatif untuk mengetahui seberapa optimalnya pembelajaran revolsi 4.0 serta seberapa pahamnya responden tentang pemberian entitas dan pengaplikasian keterampilan pembelajaran revolusi 4.0 (Junedi et al., 2020).

Instrumen yang telah disusun berdasarkan pada indikator keterampilan 4C, dimana Penelitian ini peserta didik dituntut mempunyai berbagai macam kemampuan, dan keterampilan untuk mampu bertindak secara berpengaruh serta dapat mengimbangi desakan terhadap era globalisasi dan perkembangan zaman (Simanjuntak, 2019, Septikasari, 2018).

\section{Populasi Dan Sampel}

Dalam survei penelitian ini, dilakukan dengan cara online melalui aplikasi FormApp. Dari hasil survei yang telah berperan menjadi responden penelitian ini, terkumpul sebanyak 45 orang yang terdiri dari beberapa guru, beberapa orang pelajar dari Sekolah Menengah Pertama (SMP) dan pelajar dari Sekolah Menengah Atas (SMA). Dari sampel yang diambil oleh sebagian para guru dikarenakan keahlian seorang guru juga sebagai penentu sekaligus memaksimalkan keberhasilan peserta didik dalam mengembangkan keterampilan abad 21. Penentuan topik penelitian dilaksanakan dengan teknik random sampling. Survei yang dilakukan aktif mulai dari tanggal 8 Oktober hingga 14 Oktober 2021. 


\section{Teknik Pengumpulan Data}

Pengumpulan data dilakukan menggunakan survei yang disusun melalui aplikasi FormApp / google forms dan disebar melalui via WhatsApp dan Instagram. Instrumen yang telah disusun bersumber pada analisis pustaka sesuai dengan persoalan penelitian (Aisyah et al., 2021).

\section{HASIL DAN PEMBAHASAN}

Berdasarkan pada data angket yang telah dikumpulkan selama satu minggu, baik guru maupun pelajar diwilayah Balikpapan, diperoleh sebanyak 45 data ulasan, yang terdiri dari 15 orang guru dan 30 pelajar yang dikelompokan dari 15 orang pelajar SMP dan 15 orang pelajar SMA.

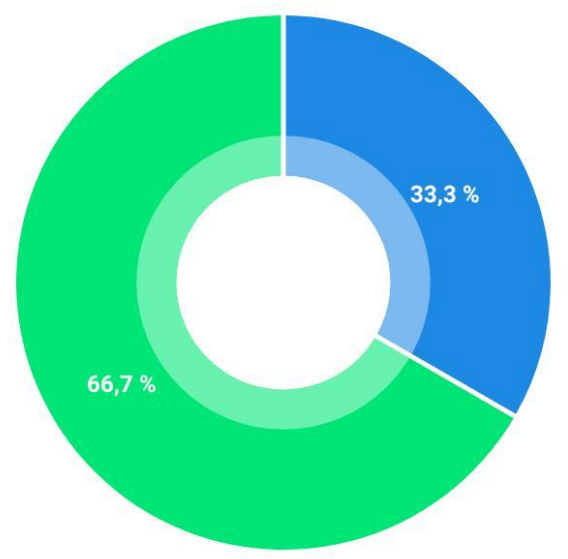

Gambar 1. Identitas pada data angket

Sebagian besar responden berasal dari guru MTs Negeri 1 Balikpapan serta responden pelajar yang diambil secara acak . Adapun hasil presentase dari data angket tentang ulasan/tanggapan responden yang disajikan pada table 1.

Tabel 1. Hasil jawaban instrument Keterampilan Pembelajaran Abad 21

Ket :

$$
\begin{array}{ll}
\text { SS } & \text { : Sangat Setuju } \\
\text { S } & \text { : Setuju } \\
\text { KS } & \text { : Kurang Setuju } \\
\text { TS } & \text { : Tidak Setuju }
\end{array}
$$

\begin{tabular}{clcccc}
\hline No & \multicolumn{1}{c}{ Item Instrumen } & SS & S & KS & TS \\
\hline 1. & $\begin{array}{l}\text { Proses pembelajaran menggunakan } \\
\text { media dikelas sudah mampu } \\
\text { membuat siswa menjadi berfikir } \\
\text { lebih kreatif }\end{array}$ & $6,67 \%$ & $73,33 \%$ & $20,00 \%$ & $0,00 \%$ \\
\hline 2. & $\begin{array}{l}\text { Menganalisis suatu permasalahan } \\
\text { dapat meningkatkan kemampuan } \\
\text { berpikir kritis siswa dalam } \\
\text { pembelajaran }\end{array}$ & & & & \\
\hline & Memberikan kesempatan kepada & $75,56 \%$ & $4,44 \%$ & $0,00 \%$ \\
\hline
\end{tabular}




\begin{tabular}{|c|c|c|c|c|c|}
\hline 3. & $\begin{array}{l}\text { siswa untuk mengemukakan } \\
\text { pendapatnya } \\
\text { menyampaikan ide di kelas }\end{array}$ & $46,67 \%$ & $53,33 \%$ & $0,00 \%$ & $0,00 \%$ \\
\hline 4. & $\begin{array}{l}\text { Menggunakan kemampuan berpikir } \\
\text { kritis dapat menambah keefektifan } \\
\text { belajar terutama dalam konteks } \\
\text { pemecahan masalah secara mandiri? }\end{array}$ & $20,00 \%$ & $66,67 \%$ & $13,33 \%$ & $00,00 \%$ \\
\hline 5. & $\begin{array}{l}\text { Proses belajar mengajar guru dan } \\
\text { siswa dapat mencari sumber belajar } \\
\text { lain untuk materi pembelajaran } \\
\text { seperti E-Modul, video pembelajaran } \\
\text { dan internet }\end{array}$ & $37,78 \%$ & $62,22 \%$ & $0,00 \%$ & $0,00 \%$ \\
\hline 6. & $\begin{array}{l}\text { Memberikan kesempatan kepada } \\
\text { siswa untuk menyimpulkan } \\
\text { pembelajaran yang sudah di dapat } \\
\text { secara lisan akan meningkatkan } \\
\text { kemampuan komunikasi siswa } \\
\text { dalam proses pembelajaran }\end{array}$ & $37,78 \%$ & $53,33 \%$ & $8,89 \%$ & $0,00 \%$ \\
\hline 7. & $\begin{array}{lr}\text { Memanfaatkan teknologi } & \text { informasi } \\
\text { dan komunikasi } & \text { untuk } \\
\text { meningkatkan kinerja dalam proses } \\
\text { pembelajaran? }\end{array}$ & $31,11 \%$ & $66,67 \%$ & $2,22 \%$ & $0,00 \%$ \\
\hline 8. & $\begin{array}{llr}\text { Siswa diberikan } & \text { kesempatan } & \text { oleh } \\
\text { guru untuk } & \text { terampil dalam } \\
\text { menggunakan } & \text { teknologi } & \text { dan } \\
\text { informasi } & & \\
\end{array}$ & $37,78 \%$ & $60,00 \%$ & $2,22 \%$ & $0,00 \%$ \\
\hline 9. & $\begin{array}{l}\text { Kebebasan dan keluasan siswa } \\
\text { dalam memilih minat dan bakatnya } \\
\text { sendiri dapat meningkatkan } \\
\text { kemampuan belajarnya }\end{array}$ & $40,00 \%$ & $57,78 \%$ & $2,22 \%$ & $0,00 \%$ \\
\hline 10. & $\begin{array}{l}\text { Diberikannya kesempatan oleh guru } \\
\text { dalam membentuk kelompok diskusi } \\
\text { dapat melatih keterampilan dalam } \\
\text { belajar }\end{array}$ & $22,22 \%$ & $68,89 \%$ & $8,89 \%$ & $0,00 \%$ \\
\hline 11. & $\begin{array}{l}\text { Menghargai pendapat orang lain } \\
\text { siswa dapat mengetahui dimana } \\
\text { letak kelemahan dan kesalahannya } \\
\text { dalam proses belajar mengajar }\end{array}$ & $17,78 \%$ & $71,11 \%$ & $6,67 \%$ & $4,44 \%$ \\
\hline 12. & $\begin{array}{l}\text { Memberikan tanggung jawab oleh } \\
\text { guru untuk bekerja sama dalam } \\
\text { diskusi, siswa akan menjadi lebih } \\
\text { produktif }\end{array}$ & $17,78 \%$ & $77,78 \%$ & $4,44 \%$ & $0,00 \%$ \\
\hline 13. & $\begin{array}{l}\text { Diberikan kesempatan oleh guru } \\
\text { untuk membuat karya seni di dalam } \\
\text { pembelajaran, siswa dapat lebih } \\
\text { mengembangkan kreativitasnya }\end{array}$ & $33,33 \%$ & $66,67 \%$ & $0,00 \%$ & $0,00 \%$ \\
\hline 14. & $\begin{array}{l}\text { Memberikan kesempatan pada siswa } \\
\text { untuk aktif dalam berbagai kegiatan }\end{array}$ & $28,89 \%$ & $68,89 \%$ & $2,22 \%$ & $0,00 \%$ \\
\hline
\end{tabular}




\begin{tabular}{lllll}
\hline \multicolumn{5}{l}{ dikelas dapat lebih mengembangkan } \\
keterampilan belajarnya
\end{tabular}

Hasil data angket diatas menyatakan bahwa persentase yang memilih "Tidak Setuju" hanya terdapat pada item instrument ke $11(4,44 \%)$, dan persentase tertinggi terlihat pada pernyataan "Setuju" sekitar $77,78 \%$ pada item instrument ke 11. Dari instrumen diatas terdapat beberapa pembagian keterampilan $4 \mathrm{C}$ yang akan diuraikan dibawah ini:

\section{Comunication (Komunikasi)}

Kecakapan dalam berkomunikasi sudah seharusnya dikuasai oleh para peserta didik di abad 21 ini. Meningkatkan kecakapan komunikasi ialah dengan mendorong peserta didik untuk turut aktif dalam sebuah diskusi, berani mengemukakan pendapat atau menyampaikan sebuah ide (Simanjuntak, 2019). Selain itu, penentu keberhasilan pada abad 21 ini, diminta peserta didik untuk memperkuat kecakapan dalam teknologi informasi, serta kecakapan dalam berbicara yang dapat dipahami sehingga akan terjadinya komunikasi yang efektif.

Dari item instrumen ke 3, 6 dan 7 dapat dilihat pada tabel diatas, bahwa responden menyatakan Setuju paling tinggi presentasenya ada pada item instrument ke $7(66,7 \%)$ atau sekitar 30 responden yang menjawab. Dapat dilihat pada gambar dibabwah ini:

Sangat Setuju - 14

Setuju - 30

Kurang Setuju - 1

Tidak Setuju - 0

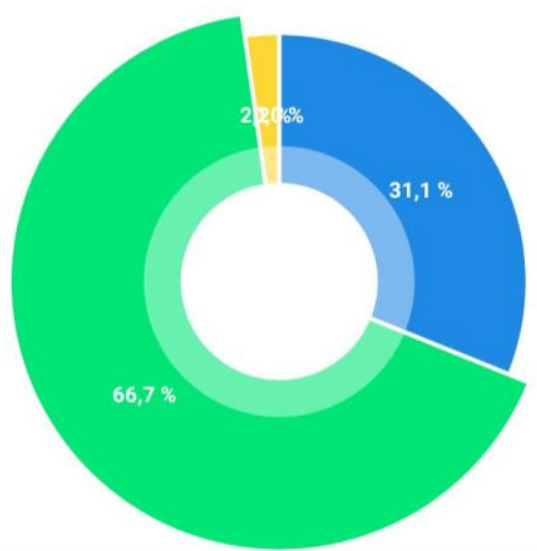

Gambar 2.Hasil jawaban responden pada item instrument ke 7 (Memanfaatkan TIK)

Hal ini sejalan dengan apa yang menjadi tuntutan atau kompetensi yang harus dimiliki oleh peserta didik dalam pembelajaran abad 21 salah satunya ialah peserta didik patut menggunakan berbagai macam teknologi dan media serta paham akan bagaimana mengukur efisiensi peserta didik sebagai pengutamaan dan memperhitungkan akibatnya (Chairunnisak, 2020).

Lalu pada item instrument ke 6 memiliki presentase tertinggi pernyataan "Kurang Setuju" dari item instrument ke 3, 6 dan 7. Dapat dilihat pada gambar dibawah ini: 
Sangat Setuju - 17

Setuju - 24

Kurang Setuju - 4

Tidak Setuju - 0

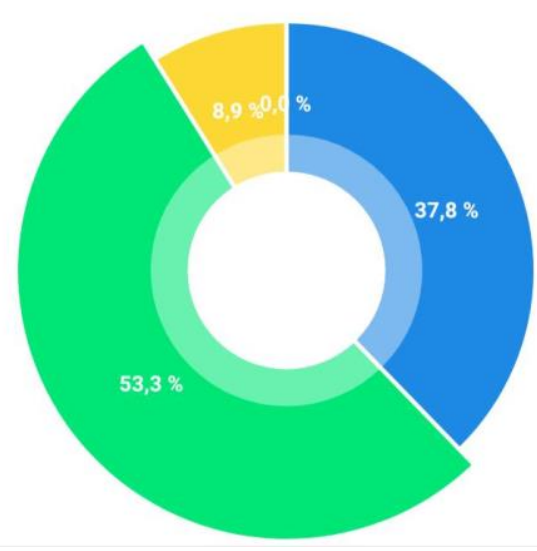

Gambar 3. Hasil jawaban responden pada item instrument ke 6 (Kesempatan Siswa dalam menyimpulkan pembelajaran secara lisan)

Terdapat sekitar 4 responden (8,9\%) yang menyatakan Kurang Setuju. Pada pernyataan ini, meningkatkan kemampuan dalam komunikasi peserta didik dalam proses pembelajaran tidaklah diukur dari bagaimana mereka bisa menyimpulkan pembelajaran secara lisan, mereka juga dapat menyimpulkan suatu pembelajaran secara tertulis. Hal ini bisa saja peserta didik mengalami kesulitan atau kurangnya kepercayaan diri mengenai pengetahuan yang ia miliki. Sehingga dalam menyimpulkan pembelajaran secara lisan akan sedikit sulit untuk mereka.

\section{Crittical Thinking (Berfikir Kritis)}

Ada 6 penanda keterampilan Crittical Thinking dalam latar belakang pembelajaran di SMA ialah, (1) merumuskan suatu permasalahan, (2) dapat meneruskan argumentargumen, (3) melakukan kesimpulan, (4) melakukan sebuah induksi, (5) melaksanakan evaluasi, dan (6) menetapkan serta mewujudkan subauh kegiatan. Seperti pada item instrument ke 1, 2, 4 dan 5 yang membahas mengenai kompetensi yang harus dimiliki pada peserta didik di abad 21. Adapun gambar diagram lingkaran dibawah ini:

Sangat Setuju - 3

Setuju - 33

Kurang Setuju - 9

Tidak Setuju - 0

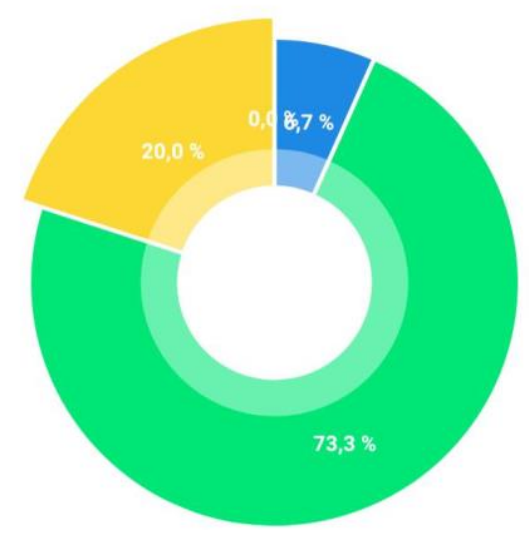

Gambar 4. Hasil jawaban responden pada item instrument ke 1(Menggunakan media dikelas mampu membuat berfikir kreatif). 
Pada hasil item instrument ke 1 lah yang menunjukkan presentase tertinggi mengenai pernyataan "Kurang Setuju" dari item instrument ke 1, 2, 4, dan 5. Terdapat 9 responden $(20,0 \%)$ yang menyatakannya. Dari hasil yang menyatakan Kurang setujunya responden terhadap penggunaan media dikelas membuat siswa menjadi lebih kreatif, dikarenakan responden belum memahami mengenai pemilihan media pembelajaran yang tepat dapat membuat peserta didik jauh lebih kreatif dalam perkembangan keterampilannya (Journal, 2016). Sedangkan mengenai pernyataan "Setuju" terdapat 33 responden $(73,3 \%)$ hal ini sejalan dengan pernyataan bahwasanya peserta didik harus ahli dalam mencari beraneka macam pemecahan masalah dari berbagai aspek yang berlainan dengan suatu permasalahan yang rumit (Prihadi, 2018), serta dalam mengkaji, memilahmilah informasi dan memecahkan sutau masalah alangkah lebih baiknya menggunakan media yang beragam agar peserta didik dapat lebih kreatif.

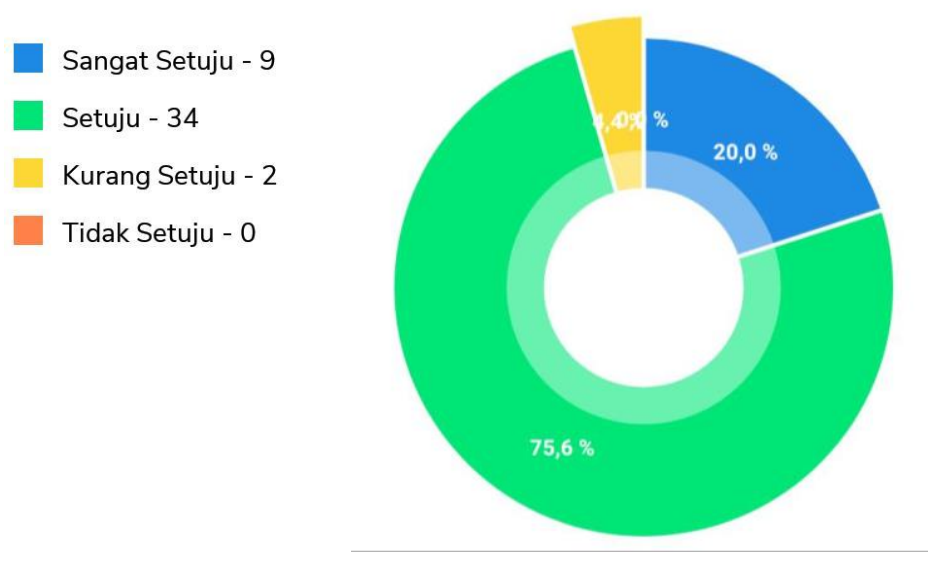

Gambar 5. Hasil jawaban responden pada item instrument ke 2 (Menganalisis suatu permasalahan)

Dan tidak kalah penting dengan item instrument ke 2 ini, hasil menyatakan presentase tertinggi dari indikator Crittical Thinking dapat dilihat pada gambar diatas, terdapat 34 responden $(75,6 \%)$ Setuju, dan 2 responden $(4,44 \%)$. Dari hasil yang lebih dominan, Setujunya responden terhadap menganalisis suatu permasalahan yang dapat meningkatkan kemampuan berfikir peserta didik dalam pembelajaran, sejalan dengan pernyataan bahwasanya keterampilan berfikir kritis melingkupi salah satunya menganalisis informasi yang dapat dijadikan materi pembelajaran.

\section{Collaboration (Kolaborasi)}

Pada item instrument ke 10, 11 dan 12 mengarah pada keterampilan kolaborasi (Collaboration). Hal yang menarik pada pernyataan ini ialah adanya responden yang menyatakan "Tidak setuju" bahwasanya dengan menghargai pendapat dapat mengetahui dimana letak kelemahan dan kesalahan dalam proses belajar mengajar. Dapat dilihat pada gambar dibawah ini: 
Sangat Setuju - 8

Setuju - 32

Kurang Setuju - 3

Tidak Setuju - 2

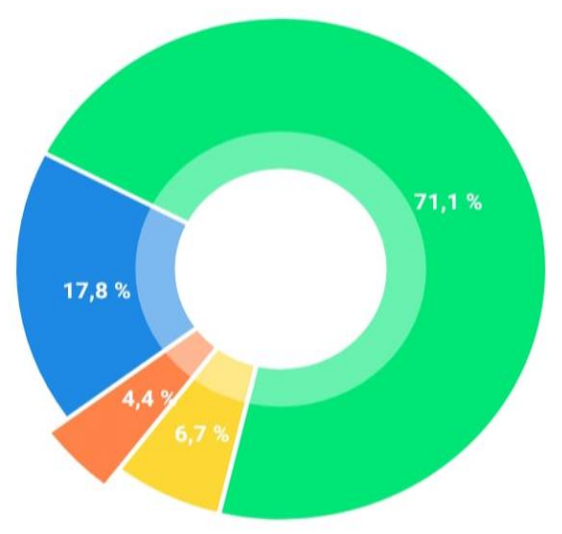

Gambar 6. Hasil jawaban responden pada item instrument ke 11 (Menghargai pendapat dapat mengetahui kelemahan dan kesalahan)

Dari hasil yang dapat dilihat, terdapat sekitar 32 responden $(71,1 \%)$ menyatakan Setuju dan 4 responden $(4,44 \%)$ yang menyatakan Tidak Setuju. Nyatanya keterampilam kolaborasi ini ialah suatu proses pembelajaran terhadap peserta didik dalam merancang sebuah kegiatan untuk saling bekerja sama dan mempertimbangkan perbedaan pendapat, mendukung sesama serta aktip dalam kegiatan diskusi kelompok (Widodo \& Wardani, 2020). Ketika peserta didik menyuarakan pendapatnya, lalu menerima ataupun menghargai kritikan dan pendapat yang lain itu tentu bisa menjadikan tolak ukur mereka agar mengetahui dimana letak kekurangan ataupun kesalahan dalam materi pembelajaran yang mereka pelajari dikelas. Ketidak setujuan responden terhadap pernyataan ini tidak dipastikan. Dikarenakan responden tidak mempunyai alasan khusus mengapa penyataan tersebut tidak disetujui.

\section{Creativity (Kreatifitas)}

Kompetensi yang harus dimiliki oleh peserta didik dalam indicator ini salah satunya ialah mewujudkan gagasan-gagasan baru yang berguna dan memanfaatkan berbagai macam metode penyusunan gagasan. Pada indikator ini, dapat dilihat pada item instrument ke 8, 9 dan 13.

\footnotetext{
Sangat Setuju - 15

Setuju - 30

Kurang Setuju - 0

Tidak Setuju - 0
}

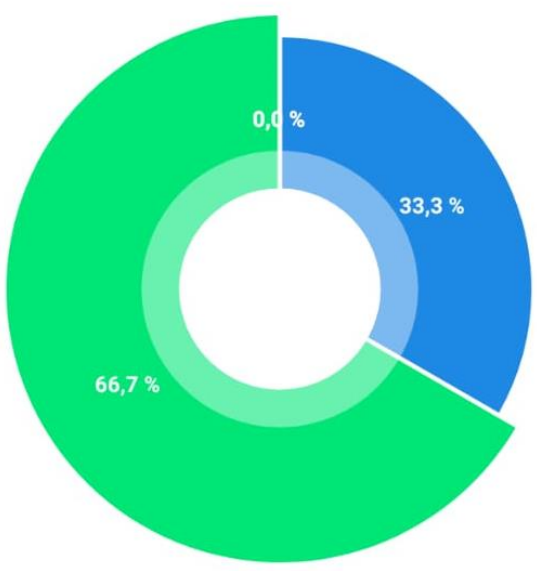

Gambar 7. Hasil jawaban responden pada item instrument ke 13 (Kesempatan untuk terampil dalam menggunakan teknologi dan informasi) 
Dari hasil gambar di atas, item instrument ke 13 menunjukkan persentase tertinggi yang menyatakan "Setuju". Hasil tersebut menyatakan terdapat 30 responden $(66,67 \%)$. Dengan diberikannya kesempatan terhadap peserta didik dalam membuat karya seni didalam pembelajaran tentunya hal ini akan memberikan peserta didik menjadi lebih mengembangkan kreativitasnya. Hal ini sejalan dengan pernyataan bahwa kreativitas ialah kemampuan memperoleh, memajukan, mendesain dan melaksanakan suatu gagasan/ide yang inovatif untuk menciptakan sebuah kreasi/karya dalam pembelajaran.

\section{KESIMPULAN}

Hasil dari penelitian ini menunjukkan bahwa didalam pembelajaran abad 21 keterampilan 4C sangatlah penting dalam tuntutan perkembangan zaman. Peserta didik yang menjadi Student Centered dan guru yang membantu mengembangkan keterampilan tersebut tentunya dapat memaksimalkan suatu pembelajaran. Dalam pemahaman antara peserta didik dan guru dalam keterampilan komunikasi, berfikir kritis, kolaborasi dan kreativitas, tentunya pembelajaran abad 21 dapat dikatakan berjalan secara optimal.

\section{UCAPAN TERIMAKASIH}

Dalam penelitian ini dapat berjalan sesuia dengan seharusnya dikarenakan kerja sama antara peneliti dengan responden yang sangat baik. Ucapan terimakasih yang sebesar besarnya kepada para responden yang telah membantu peneliti dalam menyusun mini riset ini, terkhususnya oleh guru-guru dan peserta didik yang ada di SMP dan SMA.

\section{DAFTAR PUSTAKA}

Aisyah, Salehudin, M., Yatun, S., Yani, Komariah, D. L., Aminda, N. E. R., Hidayati, P., \& Latifah, N. (2021). Persepsi orang tua dalam pendidikan karakter anak usia dini pada pembelajaran online di masa pandemi covid-19. PEDAGOGI: Jurnal Anak Usia Dini Dan Pendidikan Anak Usia Dini, 7(1), 60-75.

Aliftika, O., \& PurwantoUtari, S. (2019). Profil keterampilan abad 21 siswa sma pada pembelajaran project based learnin (pjbl) materi gerak lurus. WaPFi (Wahana Pendidikan Fisika), 4(2), 141-147.

Andrian, Y., \& Rusman, R. (2019). Implementasi pembelajaran abad 21 dalam kurikulum 2013. Jurnal Penelitian Ilmu Pendidikan, 12(1), 14-23. https://doi.org/10.21831/jpipfip.v12i1.20116

Arifin, M. Z., \& Setiawan, A. (2020). Strategi Belajar Dan Mengajar Guru Pada Abad 21. Indonesian Journal of Instructional Technology, 1(2), 37-46. http://journal.kurasinstitut.com/index.php/ijit

Astutik, P., \& Hariyati, N. (2021). Peran guru dan strategi pembelajaran dalam penerapan keterampilan abad 21 pada pendidikan dasar dan menengah. Jurnal Inspirasi Manajemen Pendidikan, 9(3), 619-638.

Baroya, E. P. I. H. (2018). Strategi Pembelajaran Abad 21 - Lpmp Jogja. Jurnal Lembaga Penjaminan Mutu Pendidikan Prov. DIYogyakarta, I(01), 101-115.

Chairunnisak. (2020). Implementasi Pembelajaran Abad 21 Di Indonesia. Prosiding Seminar Nasional Teknologi Pendidikan Pascasarjana UNIMED, 351-359.

Digital, I., \& Conference, C. (2021). Pentingnya Keterampilan Belajar di Abad 21 sebagai Tuntutan dalam Pengembangan Sumber Daya Manusia. Lectura: Jurnal Pendidikan. 12(1), 187-193.

Hadayani, D. O., Delinah, \& Nurlina. (2020). Membangun Karakter Siswa Melalui Literasi Digital Dalam Menghadapi Pendidikan Abad 21 (Revolusi Industri 4.0). Prosiding Seminar Nasional Pendidikan Program Pascasarjana Universitas PGRI Palembang, 21, 
999-1015.

Hasanah, H., \& Malik, N. (2019). Strategi pembelajaran Abad 21 bagi guru-guru SMK Kartika XX-1 Makassar. Seminar Nasional Pengabdian Kepada Masyarakat, 2019(6), 389-391. https://ojs.unm.ac.id/semnaslpm/article/view/11597

Journal, L. (2016). Lantanida Journal, Vol. 4 No. 1, 2016. 4(1).

Junedi, B., Mahuda, I., \& Kusuma, J. W. (2020). Optimalisasi keterampilan pembelajaran abad 21 dalam proses pembelajaran pada Guru MTs Massaratul Mut'allimin Banten. Transformasi: Jurnal Pengabdian Masyarakat, 16(1), 63-72. https://doi.org/10.20414/transformasi.v16i1.1963

Kartimi, K., Mulyani, A., \& Riyanto, O. R. (2019). Pemberdayaan Guru Dalam Implementasi Pembelajaran Abad 21. Dimasejati: Jurnal Pengabdian Kepada Masyarakat, 1(2), 160 170. https://doi.org/10.24235/dimasejati.v1i2.5815

Komara, E. (2018). Penguatan Pendidikan Karakter dan Pembelajaran Abad 21. SIPATAHOENAN: South-East Asian Journal for Youth, Sports \& Health Education, 4(1), 17-26.

Laksana, S. D. (2021). Jurnal Teknologi Pembelajaran ( JTeP ) Pentingnya Pendidikan Karakter Dalam Menghadapi Education Technology The 21 st Century. Jurnal Teknologi Pembelajaran (JTep), 1(1), 14-22.

Muhammad Yusri, A., \& Salmia. (2021). Peran Guru dalam Pembelajaran Abad 21 di Masa Pandemik Covid-19. Indonesian Journal of Primary Education, 5(1), 82-92. http://ejournal.upi.edu/index.php/

Ninla Elmawati Falabiba. (2019). Potensi Model Pembelajaran Pure Hypothetical Inquiry untuk Mengembangkan Kemampuan Kreatif Peserta didik pada Abad 21 di Palembang. 1(1), 247-254.

Prihadi, E. (2018). Pengembangan Keterampilan 4C melalui Metode Poster Comment pada Mata Pelajarann PAI dan Budi Pekerti. Rabbani, 5, 464-479.

Redhana, I. W. (2019). Mengembangkan Keterampilan Abad Ke-21 Dalam Pembelajaran Kimia. Jurnal Inovasi Pendidikan Kimia, 13(1).

Salehudin, M., Yatun, S., Komariah, D. L., Eka, N., \& Aminda, R. (2020). Persepsi Guru Dalam Implementasi Holistik Integratif Pendidikan Anak Usia Dini Pada Kondisi New Normal. Jurnal Golden Age, 4(02), 394-406. https://doi.org/10.29408/jga.v4i02.2767

Sari, D. R., \& Hartini, S. (2020). Pengaruh Promosi dan Lokasi Terhadap Keputusan Pembelian Pada Kedai Mie Korea ( Survei pada Pengunjung Kedai Mie Korea ). Jurnal Bisnisman: Riset Bisnis Dan Manajemen, 2(1), 31-42.

Septikasari, R. dan R. N. F. (2018). Dalam Pembelajaran Pendidikan Dasar Resti Septikasari Rendy Nugraha Frasandy Pendahuluan Sejalan dengan era globalisasi , ilmu pengetahuan dan teknologi yang berkembang sangat cepat dan makin canggih, dengan peran yang makin luas maka diperlukan guru yan. Jurnal Tarbiyah Al Awlad, VIII, 107-117.

Simanjuntak, M. D. R. (2019). Membangun Ketrampilan 4 C Siswa Dalam Menghadapi Revolusi Industri 4.0. Prosiding Seminar Nasional Fakultas Ilmu Sosial Universitas Negeri Medan, 3, 921-929.

Widodo, S., \& Wardani, R. K. (2020). Mengajarkan Keterampilan Abad 21 4C (Communication, Collaboration, Critical Thinking And Problem Solving, Creativity And Innovation) Di Sekolah Dasar. MODELING: Jurnal Program Studi PGMI, 7(2), 185-197. https://www.researchgate.net/publication/348742516

Wirawan, G., \& Sukarni, N. (2013). Analisis Keterampilan Abad 21 Dalam Pembelajaran Ips Secara Garing Di Smp Negeri 5 Jember. Journal of Chemical Information and ModelingJournal of Chemical Information and Modeling, 53(9), 1689-1699.

Zakaria. (2021). Kecakapan Abad 21 Dalam Pembelajaran Pendidikan Dasar Masa Pandemi Covid-19. Jurnal Dirasah, 4(2), 81-90. https://stai-binamadani.ejournal.id/jurdir/article/view/276 